\title{
'It's Our Patriotic Duty to Help Them': the Socio-Cultural and Economic Impact of the 'Solidarity wave' on Canadian and Polish- Canadian Society in the Early 1980s
}

Michal Mlynarz, University of Alberta

56 This paper examines the economic, social, and cultural impact made on Canadian and Polish-Canadian society as a result of the mass influx of refugees from the People's Republic of Poland to Canada in the early to mid 1980s. Although a brief overview and examination of Polish immigration history to Canada over the last few centuries is provided, the paper focuses upon the significant effect caused by the arrival of a new wave of Polish immigrants, largely consisting of highly educated and politically vocal individuals, into the country.

The paper argues that this period constituted a significant turning point in Polish-Canadian history. Throughout this period, Polish communities across the country organized and rallied around the plight of the refugees and their ancestral homeland in an

unprecedented fashion, supporting them through a wide variety of means, including the mass organization of protests, food and medicine drives, and sponsorship schemes to bring in as many people as possible. Mainstream Canadian society was also made more aware of and became more involved in the issue, with both politicians and average citizens nation-wide lending their support to the cause.

As a result of the unique socio-cultural nature of the refugees, the great level of support displayed by Polish-Canadians, and the significant level of sympathy and involvement demonstrated by mainstream Canadian society, the paper argues that the 'Solidarity

Past Imperfect

13 (2007) | @ | ISSN 1192-1315 
Wave' helped lead both to a radical social and economic restructuring of Polish-Canadian society, as well as serving as a strong example of the ways through which an ethnic group can impact upon the wider social and political dynamics of the state of which they constitute a part of, as well as analyzing the effects that refugee and sudden immigration influxes can play upon an established ethnic community.

According to the 2001 Canadian Census, out of an estimated population of 29,639,035 people, 817,085 respondents reported some Polish ancestry, ${ }^{1}$ with 208,375 of them claiming Polish as their mother tongue. ${ }^{2}$ The Polish lands, along with areas of Germany, Sicily and Ireland, have been amongst the greatest suppliers of European immigrants to other nations. Norman Davies claims that over one-third of all ethnic Poles live abroad. ${ }^{3} \mathrm{He}$ further estimates that between nine to ten million people of Polish descent live abroad, and that a global estimate of people of Polish heritage may very likely constitute nearly 15 million. ${ }^{4}$ With their considerable numbers and long history in Canada, Henry Radecki believes that Polish Canadians constitute one of the largest 'tiles' of the 'Canadian

\footnotetext{
${ }^{1}$ Census of Population, Statistics Canada, 2001 Census. http://www40.statcan.ca/101/cst01/demo26a.htm (May 21, 2007)

${ }^{2}$ Canadian Statistics - Population by Mother Tongue, by Provinces and Territories (2001 Census). http://www40.statcan.ca/101/cst01/demo11b.htm.(May 21, 2007)

${ }^{3}$ Norman Davies, Gods Playground: A History of Poland, Volume II: 1795 to the Present (New York: Columbia University Press, 2005), 202-205.

${ }^{4}$ Davies, God's Playground, 205.
} 
Mosaic'. ${ }^{5}$ Polish immigration to Canada consisted of four waves, the first being a small group of professionals who had already begun to arrive by $1792 .^{6}$

The most recent, vocal, and political of these waves saw a large number of young professionals enter Canada in the early 1980s. ${ }^{7}$ Although examining the role that the Polish people have 58 played in Canada over their long history in the country, this paper will maintain a particular focus upon the political, economic, and cultural impact of the 'Solidarity Wave'. The founding and unprecedented success of the 'Solidarity' movement in September of 1980 brought with it a flurry of social and political conflict in Poland, eventually resulting in the de-legalization of the movement and the declaration of Martial Law in December of the following year. This set into motion a mass movement of refugees who sought to flee the country, selecting Canada as one of their favored destinations. Along with this mass movement of people came a significant mobilization on the part of Polish-Canadian organizations to assist the refugees and their land of origin in every way they could. This included such activities as the lobbying of the Canadian government to denounce and boycott the People's Republic of Poland, the organization of food and medicine drives, the staging of

\footnotetext{
${ }^{5}$ Henry Radecki, Ethnic Organizational Dynamics: The Polish Group in Canada (Waterloo, ONT: Wilfrid Laurier University Press, 1979), xvii.

${ }^{6}$ William Makowski, The Polish People in Canada: A Visual History (Montreal: Tundra Books, 1987), 1-3.

${ }^{7}$ In the historiographical literature on the topic, as well as within the pages of various Polish-Canadian newspapers, this group is variously termed an 'enigmatic third wave', 'a wave of individuals', or the 'Solidarity Wave'. In this paper, I will refer to it as the 'Solidarity Wave', as I feel that this term is one that most accurately describes the socio-political makeup of the people that constitute it. I will thus use this term when making reference to Polish refugees that arrived in Canada during the early to mid 1980 s.

Past Imperfect

13 (2007) | @ | ISSN 1192-1315
} 
massive protests, and the formation of programs designed to sponsor and to acclimatize new immigrants into Canadian life. ${ }^{8}$

As a result of the political, economic, and social actions undertaken by Canada's Polish communities in their support for Solidarity and the refugees, the very social fabric of Polish-Canadian society itself was significantly altered, this period constituting a considerable turning point in Polish-Canadian history. A community that had, by that point, seen several of its generations born in Canada and that had become firmly entrenched within Canadian society was faced with the prospect of supporting tens of thousands of highly political and vocal refugees from their land of origin, who had grown up not in a relatively free Western society but amidst the political turmoil of post-War, Communist Poland. This crisis saw Polish organizations and communities across the country rally to their support and significantly involve themselves in every way they could, thus changing the degree to which Polish-Canadian organizations dealt with Poland and its political circumstances, making the community more actively involved with and aware of their land of origin, and accelerating processes of mutual exchange between the communities that had been started in the 1950s. At the same time, the influx of a new first-generation into Polish-Canadian circles led to questions over how they would be integrated into and become accepted by Polish-Canadian and mainstream Canadian society. As a result of the extensive lobbying by Polonia

\footnotetext{
${ }^{8}$ The socio-economic makeup of the Polish community in Canada is quite vast, encompassing people who may be third or fourth generation born in Canada, as well as people whose parents or themselves were born in Poland and may have arrived in the country in recent decades or years. In an effort to avoid confusion, I will use the term Polonia (which is used by Polish communities both in Canada and throughout the world in order to describe themselves) when referring to Polish-Canadians and their organizations. This term can be variously used to describe people of different generations and of different degrees of cultural awareness, in addition to their specific religious, cultural, and political clubs and groups.
} 
organizations to the Canadian government and society, the community achieved a degree of success in providing for increased levels of funding, refugee assistance, and local and national awareness of the refugees and of Poland's situation within the eyes of the 'average' Canadian and politician. In the European sphere, the Solidarity crisis provided the spark that eventually helped lead to the downfall of the People's Republic of Poland and of the entire Soviet empire; in Canada, however, it helped lead to a radical restructuring of ethnic group dynamics and political participation, providing for a strong case study in how 'ethnic' politics may sometimes work to influence and change not only the structure of the group and community itself, but of the structure and awareness of the greater society of which they are a part of itself.

The Polish people have a long history of migration, entering other countries under diverse social, political, economic, and cultural circumstances. Starting in the 1840 s, and particularly during the late nineteenth century, permanent economic migration to other nations, including France, the United States, and Canada, began. ${ }^{9}$ By the 1870s, a more regular movement of Poles to Canada had begun. The majority of these immigrants were peasants, living a stagnant agricultural life with little change and few prospects for optimism. They encountered a great deal of frustration, discrimination, and hardship upon their arrival in Canada. ${ }^{10}$ D.H. Avery and J.K. Fedorowicz estimate that around 110,000 Poles came to Canada between 1896 and $1914 .^{11}$ The majority of these immigrants settled on farms, but a significant number moved to Winnipeg. The first

\footnotetext{
${ }^{9}$ Norman Davies, God's Playground: A History of Poland, Volume II: 1795 to the Present (New York: Columbia University Press, 2005), 202-204.

${ }^{10}$ Ibid., 47-49.

${ }^{11}$ D.H. Avery, J.K Fedorowicz, The Poles in Canada (London, ON: University of Western Ontario, 1982), 4-6. 
forms of organizational life were centered around the Roman Catholic Church, which had played a significant role in traditional village life. $^{12}$

Following WWI, partitioned Poland was re-united as an independent, Polish Republic. This unity brought with it many political and economic problems, and the new Polish government began to encourage emigration in order to help the country stabilize. ${ }^{13}$ Between 1920 and 1939, about 52,000 Poles entered Canada, many of them settling in Ontario and in major eastern centers, during which time Polish institutions, particularly the Roman Catholic Church, experienced positive growth. ${ }^{14}$ These groups were more politically and nationally conscious than the first wave, haven taken part in or witnessing the recent national struggles, holding a higher level of formal education, and also possessing a higher level of participation in voluntary organizations ${ }^{15}$. A third wave of Polish immigration began in 1939. With the opening of WWII, the Canadian government encouraged the emigration of several hundred highly educated scientists and technicians. Following the War, a large number of army veterans were admitted from different parts of Europe. ${ }^{16}$ Radecki claims that 64,096 Poles were accepted during this period. ${ }^{17}$

After overcoming some of the initial challenges faced with the trying experiences of immigration, Polish organizational life in

\footnotetext{
${ }^{12}$ Ibid., 7-10. Although there were over sixty Polish place names in Canada by 1967 , it is difficult to ascertain as to whether this was a result of Polish lobbying and influence or a specific governmental policy in the selection of settlement names. Makowski, History and Integration of Poles in Canada, 241-243.

${ }^{13}$ Avery and Fedorowicz, The Poles in Canada, 10-11.

${ }^{14}$ Ibid., 10-11.

${ }^{15}$ Radecki, Ethnic Organizational Dynamics, 66-67.

${ }_{17}^{16}$ Avery and Fedorowicz, The Poles in Canada, 12-13.

${ }^{17}$ Ibid., 35-36.
} 
Canada eventually began to flourish. ${ }^{18}$ The first such organizations were Roman Catholic parishes, in particular the Polish Oblate Fathers, who organized Polish-language sermons, ethnic organizations, and, eventually, Polish language periodicals. ${ }^{19}$ The new tide of immigrants entering the country between 1921 and 1931 breathed new life and incentive into organized groups and parishes, and ultimately led to the organization of larger Conventions and the founding of Polish Consulates in Canada. ${ }^{20}$ Polonia groups organized various forms of post-war assistance for Poland, including the channeling of aid and the sponsorship of war refugees to Canada. In 1944, 115 groups were amalgamated into the Canadian Polish Congress. By 1946, it had become focused upon representation, unity, and the provision of assistance to newly arrived Polish immigrants and to Poland itself, making the crucial distinction that they were representing Canadians of Polish descent, and not Poles living in Canada. ${ }^{21} 22$ One of the most important and influential activities of Polish organizational life in Canada has been that of the Polish language press. These periodicals contain a wealth of information, including accounts on settlement, organizational activities, debates and controversies within the community, and adjustment into Canadian society. ${ }^{23}$ The first Polish language

\footnotetext{
${ }^{18}$ Ibid., 10-14.

${ }^{19}$ Ibid., 48-50.

${ }^{20}$ Heydenkorn, The Organizational Structure of the Polish Canadian Community, 132-204.

${ }^{21}$ Radecki, Ethnic Organizational Dynamics, 77-81.

${ }^{22}$ The actions and conventions of the Canadian Polish Congress are described in detail by Heydenkorn (1979). Viktor Turek, the first serious researcher and scholar on Polish-Canadian history and culture, helped found the Toronto based Canadian Polish Research Institute, which focuses upon the documentation and preservation of as much information as possible on the Polish group in Canada (Heydenkorn, 7$10)$.

${ }^{23}$ Victor Turek, The Polish-Language Press in Canada: Its history and a bibliographical list (Toronto: Polish Alliance Press Limited, 1962), 11-22. Past Imperfect 
newspaper in Canada was the Winnipeg-based Gazeta Katolicka (Catholic Gazette), founded between 1904-08. ${ }^{24}$ Many others followed, some focused upon the dissemination of Communist ideals, such as Budzik (Alarm Clock), others on humor, such as Bocian (Stork). ${ }^{25}$ In analyzing the Solidarity Wave, this paper will draw upon a selection of articles published within Czas (The Times) and the Kurier Polsko-Kanadyjski (The Polish-Canadian Courier) during the early to mid-1980s, which have provided for a comprehensive set of sources for the many events, appeals, and activities organized by Polish communities throughout Canada during the early 1980 s. $^{26}$

Although Poles have been permanently settled in Canada for over a century, the dramatic events of the past two decades have served to cement both Polish Canadians and Poland itself more firmly within the public eye of Canadian society. This section will discuss these arrivals from the People's Republic of Poland (Polska Rzeczpospolita Ludowa), or PRL. ${ }^{27}$ It will closely examine the activities of Polonia organizations during this time, particularly in how they related to interactions with Poland and the Canadian government and society, examining the reaction of the Canadian and Polish governments and public to the political crisis and the ensuing influx of refugees that followed it.

${ }^{24}$ Ibid., 98-99.

${ }^{25}$ Ibid., 98-138.

${ }^{26}$ Viktor Turek has written a comprehensive study dealing with the history, circulation, and content of Polish-Canadian newspapers. Czas is one of the oldest of these newspapers, and was first published in Winnipeg in 1915, maintaining a regular format ever since. Detailed information on its circulation between the years 1917-1960 is available in Turek, 110-115.

${ }^{27}$ I will use the term PRL to refer to the socialist government of Poland from the years 1945-1989. Although the terms Socialist and Communist have been variously used to describe this government, they hold multiple definitions and interpretations. PRL proves for the most specific historical and socio-political meaning. 
Between 1956-1980, around 900,000 immigrants were admitted into Canada from the countries of 'East Central Europe', an encompassing term that includes Poland, Czechoslovakia, Hungary, Romania, Yugoslavia, and Albania. The largest numbers came from Poland, Hungary, and Yugoslavia. ${ }^{28}$ Many professionals and intellectuals entered Canada during this time period. ${ }^{29}$ In the mid64 1920s, the USSR had adopted a 'no-exit' policy regarding emigration, which it viewed as being counter-productive in economic terms. ${ }^{30}$ It wanted its citizens to stay in the country in order to help it rebuild according to the regime's desired economic and political goals. The government viewed emigration as a form of social protest against the state, which it wanted to curtail. ${ }^{31}$ The monopolization of resources, the maintenance of the status quo within the bloc and the maintenance of cordial relations with Soviet Russia were of the utmost importance to the government of the PRL. In the late 1950s, citizens of Western countries were allowed to visit Poland, in the process leading to the establishment of a network of social and economic relations with their families there. The PRL government wanted to maintain a positive image of itself outside of its borders, and saw Polonia communities around the world as playing a crucial role in the achievement of that goal. They employed a variety of tactics in order to impose social control on immigrants returning to the country, including passport blackmail and police harassment.

\footnotetext{
${ }^{28}$ Leszek A. Kosinki, 'Immigration from East Central Europe to Canada, 1956-80', in Central and East European Ethnicity in Canada: Adaptation and Preservation (Edmonton, AB: Central and East European Studies Society of Alberta, 1985), 9-23. ${ }^{29}$ Alexander J. Matejko, 'Polish Canadians in the 1980's: Issues and Problems', in Central and East European Ethnicity in Canada: Adaptation and Preservation (Edmonton, AB: Central and East European Studies Society of Alberta, 1985), 293296.

${ }^{30}$ Delali Margaret Badasu, Polish Immigration to Alberta since 1980: determinants and consequences (Unpublished MA thesis, University of Alberta, 1990), 50-52. ${ }^{31}$ Ibid., 50-52. 
Jacek Adolf claims that the PRL frequently maintained social and economic relations with certain key individuals within Canadian Polonia organizations. ${ }^{32}$

In the Polish-Canadian press of the early 1980s, it was frequently emphasized that relations between Poland and Poles abroad were becoming stronger and more influential than they ever had before. A February 1981 Czas article discussed how PRL authorities were attempting to exploit this relationship to their advantage and to weaken political centers of activity in both communities. ${ }^{33}$ Other articles emphasized the sheer number of 'countrymen' around the world, and the great advantages that this situation could potentially hold for improving Poland's lot. On the official 'Day of Emigration' celebrated in Poland, it was emphasized that people of Polish origin could, on occasion, be better patriots than Poles themselves. ${ }^{34}$

In 1976, Canada made extensive changes to its refugee policy, formalizing three separate ways through which refugees could be resettled within the country. This included the creation of a special category of 'displaced and persecuted persons', who did not need to meet regular criteria of selection, and who could be sponsored by a private organization or the government. In 1978, more liberal rules were created for organizations or individuals who had the intention of sponsoring refugees, for whom they would agree

\footnotetext{
${ }^{32}$ Jacek Adolf, 'Immigrant Adaptation and Simultaneous Involvement of Immigration Group in Two Social Systems in Conflict', in From Prairies to Cities: Papers on the Poles in Canada at the VIII World Congress of Sociology (Toronto: Polish Alliance Press Limited, 1975), 61-67.

33 'Kraj i Emigracja: Zespó_Problemowy PPN', Czas, Nr. 6, Saturday, February 7, 1981, 1.

34 'Dzie_Emigranta - Dniem Solidarno_i z Rodakami za Granic_', Czas, Saturday, October 24, 1981, 1; 'Manifestacja Solidarno_i', Czas, Nr. 23, Sunday, June 12, 1982, 1; 'Nades_ane z Kraju: specjalnie dla Tyg. 'Czas': Pos_anie Polaków w Kraju do Polaków za Granic_', Czas, Nr. 25, Saturday, June 26, 1982, 1.
} 
to provide support to for a year. ${ }^{35}$ Soon afterwards, on January 21, 1979, three new classes of refugees were created, which included the group Eastern European Self-Exiled Persons, allowing the admission of individuals who did not meet the definition of the U.N Convention on refugees. There were both political and ideological influences in the formation of this policy, which, during the Cold War, was quite 66 liberal towards potential Eastern European immigrants, ${ }^{36}$ Western states frequently interpreting immigration requests from Eastern bloc countries as 'defections', and thus taking special measures to accommodate them. These concessions were established partly due to the lobbying of Polonia organizations on the issue. ${ }^{37}$ In reaction to the imposition of martial law in December of 1981, visiting Poles in Canada were allowed to apply for landed-immigrant status from within the country. ${ }^{38}$

The largest wave of Polish immigrants to arrive in Canada over the past two decades was during the early 1980s. ${ }^{39}$ According to an analysis of the Immigration Statistics of Employment and Immigration Canada, 1,185 new immigrants whose country of last permanent residence was Poland landed in Canada in $1980 .{ }^{40}$ There was a marked increase the following year, which saw 3,850 people land, ${ }^{41} 8,278$ in $1982,{ }^{42}$ and 5,094 in $1983 .^{43}$ This new wave was both

\footnotetext{
${ }^{35}$ Ninette Kelley and Michael Trebilcock, The Making of the Mosaic: A History of Canadian Immigration Policy (Toronto: University of Toronto Press, 2000), 404405.

${ }^{36}$ Ibid., 406.

${ }^{37}$ Badasu, Polish Immigration to Alberta since 1980, 62-63.

${ }^{38}$ Ibid., 409.

${ }^{39}$ Matejko, 'The Polish Experience in Alberta', 87-89.

${ }^{40}$ Employment and Immigration Canada: Immigration Statistics, 1980, 13, in Citizenship and Immigration Canada,

http://www.cic.gc.ca/english/research/index.html. (May 21, 2007)

${ }^{41}$ Employment and Immigration Canada: Immigration Statistics, 1981, 13, in Citizenship and Immigration Canada,

http://www.cic.gc.ca/english/research/index.html. (May 21, 2007)

Past Imperfect 
unexpected and vastly different from the ones preceding it. Both communities were required to make great adjustments in order to help cope with the situation. ${ }^{44}$ During the height of the conflict the PRL government adopted a forced emigration policy against thousands of more vocal and political Solidarity activists, offering them the option to leave the country rather than be interred. ${ }^{45}$ Many of the new arrivals were young and well educated, revitalizing political interest in Polonia organizations and inspiring many in the community to take a more active role in the promotion of Poland and its struggles. ${ }^{46}$ Their arrival sparked off a debate within Polonia circles, in which they were termed an 'enigmatic third wave' and the first 'immigrant wave of individuals' by a 1981 Kurier opinion article, with questions being raised over where they would fit in with the community and whether a conflict of generations would occur as a result.

The Canadian Polish Research Institute sponsored a memoir competition of immigrants who entered the country between 19811989. Many of the conclusions from these memoirs match those of Badasu's study. The immigrants were younger, came from an urban background, and were highly educated and adamantly opposed to the PRL government. Many of them are seen as being highly loyal and homesick, with professionals upset at the lack of recognition of their

${ }^{42}$ Employment and Immigration Canada: Immigration Statistics, 1982, 31, in Citizenship and Immigration Canada,

http://www.cic.gc.ca/english/research/index.html. (May 21, 2007)

${ }^{43}$ Employment and Immigration Canada: Immigration Statistics, 1983, 37, in Citizenship and Immigration Canada,

http://www.cic.gc.ca/english/research/index.html. (May 21, 2007)

${ }_{44}$ Matejko, 'Polish Canadians in the 1980's: Issues and Problems', 90-91.

${ }^{45}$ Badasu, Polish Immigration to Alberta since 1980, 51-52.

Matejko, 'Polish Canadians in the 1980's: Issues and Problems', 90-93.

${ }^{46}$ Matejko, 'Polish Canadians in the 1980's: Issues and Problems', 90-93;

'Enigmatyczna 3-cia Fala', Kurier Polsko-Kanadyjski, Nr. 18 (350), November 7, 1981, 1 . 
qualifications. In their attitudes to organizational life, many were highly appreciative of church life, which they saw as an extension of social and spiritual life in Poland. Heydenkorn claims that they held somewhat critical and paternalistic views towards the older generations of Polish immigrants, on occasion considering themselves to be culturally superior to them. ${ }^{47}$ In many cases, these individuals have been defined as 'refugees'. Several key shared experiences have been identified in the plight of refugees. These include perceptions of threat, the undertaking of a decision to escape, a period of flight and of experienced danger, the eventual reaching of safety, readjustment, and behavioral change that occurs as a result of the experience. Occasionally included is a period of time spent in a refugee camp, coupled with the experiences associated with eventual repatriation or resettlement. The majority of these criteria could be applied to many of the Solidarity migrants. ${ }^{48}$

The 1980-1983 period played a highly transformative role in the relationship between Polonia organizations and Poland itself, sparking off a new wave of interest amongst Poles throughout Canada in providing assistance. ${ }^{49}$ During this period, the Canadian Polish Congress involved itself to a great extent in refugee and Polish affairs. It lobbied the Canadian government to make political demands of the PRL and to assist the Solidarity movement, and it helped to organize various funds and organizations in order to provide refugees with food and medicine. ${ }^{50}$ It declared its solidarity with Poland, organizing protests, strikes, and demonstrations all over

\footnotetext{
${ }^{47}$ Benedykt Heydenkorn, ed. Many Faces of Canada: Memoirs of Polish Immigrants, 1981-1989 (Toronto: Canadian Polish Research Institute, 1990), 1-12.

${ }^{48}$ Badasu, Polish Immigration to Alberta since 1980, 124.

${ }^{49}$ Matejko, 'Polish Canadians in the 1980's: Issues and Problems', 90-93.

${ }^{50}$ Canadian Polish Congress, 1980-1982 (Winnipeg, MB: Canadian Polish

Congress Convention, 1982), 1-15.

Past Imperfect

13 (2007) | @ | ISSN 1192-1315
} 
Canada, as well as arranging meetings with Canadian ministers and government officials. This included the avocation of support for International Solidarity Day on January 30, $1982,{ }^{51}$ relief funds, marathons, telethons, and food drives. ${ }^{52}$ At one point, the Congress wanted to encourage Lech $\mathrm{Wa}_{\text {__sa, }}$, the leader of the Solidarity movement, to visit Canada, although the political circumstances made this impossible. ${ }^{53}$ Similar movements were undertaken by the Diamond Jubilee of the Polish Alliance of Canada, including the establishment of a special committee for refugees and the advocating of the Canadian government to modify immigration rules and to arrange for sponsors and other forms of assistance. ${ }^{54}$ In 1980, the organization donated money to $\mathrm{Wa} \_$sa and the Solidarity Movement. $^{55}$

Protest activities were regularly organized by Polonia organizations, often in conjunction with local or national politicians and groups. By the end of 1981, appeals distributed in Polish Canadian newspapers for support raised around $\$ 700,000$ for Solidarity. ${ }^{56}$ Following the declaration of Martial Law, a demonstration against it was held at the Polish consulate in Toronto, during which time an appeal was made to the Canadian government to cut its ties with the PRL government. ${ }^{57}$ Similar protests were held in other countries, including a pro-Solidarity rally in front of the Polish embassy in Vienna. ${ }^{58}$ By late December, the Canadian Labor

${ }^{51}$ Ibid., 22-23.

${ }^{52}$ Ibid., 28-30

${ }^{53}$ Ibid., $45-47$.

${ }_{55}^{54}$ Canadian Polish Congress, 1980-1982, 75-77.

${ }^{55}$ Ibid., 80-82.

${ }^{56}$ Zdzis_aw Przygoda, 'Polish-Canadian Press', The Globe and Mail, Thursday, November 5, 1981, 9.

57 James Hendry, 'Thousands Stage Rally in Toronto', The Globe and Mail, Saturday, December 12, 1981, 10.

58 'Serious concern over Poland, Haig Says', The Toronto Star, Monday, December 14, 1981, A12. 
Congress began to lobby and raise funds for the establishment of a Solidarity office in Toronto, ${ }^{59}$ during which time the Polish Canadian Congress sent appeals to Canada to toughen its stance on the issue, as well as to help raise funds, claiming that they had raised almost one million for medicine and food. ${ }^{60}$ The Ontario government also made monetary contributions for refugees in Canada and in Austrian 70 camps. ${ }^{61}$ A great deal of activity was organized within Polonia circles to lobby for and to collect various forms of material and financial aid for Poland. The extent to which Polonia community's had become financially and emotionally involved in helping their country of origin was made manifest in a November 1981 appeal, wherein the Refugee Committee of Manitoba stated that 'helping Polish refugees is our patriotic duty! ${ }^{, 62}{ }^{63}$ Appeals for aid to Polonia groups were issued from the Polish Government in Exile in London, England, ${ }^{64}$ and from the Polish Canadian Congress, who stated that it was the responsibility of the world's Polonia communities both to help Poland and to remind the society that they were a part of the importance of the values represented by Solidarity and to denounce Martial Law and political persecution. ${ }^{65}$ Many different Polonia and Canadian governmental organizations and agencies worked in

59 'CLC helping Solidarity to open Toronto office', The Globe and Mail, Wednesday, December 23, 1981, 11.

${ }^{60}$ Margaret Mironowicz, 'Poles to press McGuigan for help', The Globe and Mail, Wednesday, December 23, 1981, 11.

61 'Ontario to donate \$33,950', The Globe and Mail, Wednesday, December 23, 1981, 11

62 'Pomó_Polskim Uchod_com', Czas, Saturday, November 21, 1981, 7.

${ }^{63}$ Although it is unclear from the article whether this refers to patriotism to Canada or to Poland, the fact that such a statement was published in Czas and under the aegis of a Canadian organization lends support to the fact that it is likely a 'patriotic duty' towards the wider Polish community itself, including support for the new arrivals.

64 'Delegat Rz_du Rzeczpospolitej Polskiej na Kanad_', Czas, Nr. 3, January 22, $1982,2$.

65 'Odezwa Kongresu Polonii Kanadyskiej na Dzie_13 Grudnia 1982 r.', Czas, Nr. 50, December 18, 1982, 2.

Past Imperfect

13 (2007) | @ | ISSN 1192-1315 
tandem in this regard. In January of 1982, in conjunction with the Hungarian association in Sudbury, Ontario, \$250,000 was raised for workers in Poland, an additional \$50,000 being raised with help from the local Folk Arts Council. ${ }^{66}$ In March of that year, an MP of Polish descent helped organize for the donation of $\$ 200,000$, and in conjunction with the president of the Polish-Canadian Congress, Jan Kaszub, the collection of $\$ 100,000$ was organized. ${ }^{67}$ At this time, Kaszub obtained agreement from the Ministry of Immigration to ask for help all over Canada, with the Central Immigration Commission being established in Toronto for this purpose. ${ }^{68}$ A Food for Poland campaign was established in January $1981 .^{69}$

Polonia organizations also worked to bring in important political figures opposing the PRL regime to visit Canada. In November 1981, still prior to the declaration of Martial Law, Wies_aw Chrzanowski, a professor and Solidarity member, embarked on a speaking tour through Montreal, Toronto, Hamilton, and London, Ontario. ${ }^{70}$ On March 12, 1983, Kazimierz Sabbat, the Minister of Immigration from the Government in Exile ${ }^{71}$ visited Thunder Bay, Ontario, and Winnipeg, Manitoba. During his visit, Sabbat attended a Mass for Poland and a large gathering in the local

66 'Kronika z Sudbury’, Kurier Polsko-Kanadyjski, Nr. 6, March 21, 1982, 2.

67 'Pomoc Kanadyjska skadla Polski', Kurier Polsko-Kanadyjski, Nr. 7, April 7, $1982,4$.

68 'Apel Kongresu Polonii Kanadyjskiej', Kurier Polsko-Kanadyjski, Nr. 11, June 7, 1982, 2.

69 ‘Apel Kongresu Polonii Kanadyjskiej’, Czas, Nr. 4, Saturday, January 24, 1981, 2.

70 'Prof. Chr_anowski z 'Solidarno__i' w Kanadzie', Czas, Nr. 19 (351), November 21, 1981, 2.

${ }^{71}$ The Polish Government in Exile was established in September 1939 following the invasion of the country by Nazi Germany, and remained in existence until the collapse of the Soviet Union and the fall of the PRL. Both during and after the War, it coordinated efforts to resist Nazi and Communist rule, and in 1990 it was officially recognized as the legitimate successor government of Poland. 
Polish Hall, meeting with groups of Polish emigrants residing in Canada and the United States. ${ }^{72}$

Polonia organizations helped to organize various forms of public protest throughout Canada in the early 1980s. Most often, these took the form of public demonstrations, involving not only members of the Polish community, but also members, 72 representatives and clergy of other ethnic groups, in particular from other nations of East-Central Europe and the Soviet Bloc. On December 14, 1980, a major protest and Mass for peace was organized in Montreal. At this time, collections for food were made and appeals were directed to the nations of the Helsinki Accord. ${ }^{73}$ In April 1981, a major protest was held in Calgary, where the imprisonment of political prisoners by the PRL was denounced. At this time, a Committee of Co-Operation Between the Nations of Eastern Europe was formed. ${ }^{74} \mathrm{~A}$ similar event was held in Edmonton, as the Soviet flag was burnt and the Polish raised for two days. ${ }^{75}$ On April 26, a protest was organized in Winnipeg, participants waving Solidarity banners with likenesses of Wa_sa. ${ }^{76}$ Under the call of 'Solidarity - A Step towards Freedom', the publishers of Czas prepared for an action of car protest, selling Solidarity car stickers in bulk. ${ }^{77}$ Another major protest was held in Winnipeg in December 1981 under the steps of Parliament, where a

\footnotetext{
72 'Premier Rz_du R.P. na Emigracji Przybywa do Winnipegu', Czas, Nr. 10, March 12, 1983, 1; 'Premier Rz_du R.P. na Emigracji K. Sabbat w Winnipegu', Czas, Nr. 12, March 26, 1983, 1.

73 'Korespondencja z Montrealu: msza swi_ta w Intencji Pokoju dla Polski', Czas, Nr. 9, Saturday, February 28, 1981, 5.

74 'Demonstracja w Calgary', Czas, Saturday, April 11, 1981, 4.

75 'Polonia Edmontonska Domaga si_Uwolnienia Wi_niów Politycznych PRL', Czas, Saturday, April 25, 1981, 4.

76 'W obronie L. Moczulskiego I Wi_niów Politycznych', Czas, Saturday, May 9, $1981,1$.

77 'Solidarno_"'- To krok do Wolno_ci', Czas, July 4, 1981, 1. 
Soviet flag was burned and demands were issued to the federal government to boycott technological sales to the Soviet Union, to place embargoes on it, to free Polish political prisoners, and to open up Poland's borders to allow more refugees to flee. ${ }^{78}$ The Ukrainian community regularly lent support to Poland's cause. ${ }^{79}$ A December 1981 demonstration in Edmonton saw Celestyn Suchowrsky deliver a powerful speech of support, in which he argued that the Soviet Union was to blame for recent events and that its army was running rampant in Poland and murdering people. ${ }^{80}$ In May 1982, a Religious-Patriotic Manifestation was organized in Winnipeg's Kildonan Park and repeated every thirteenth day of the month, wherein Polonia communities throughout Canada were asked to turn off their lights and to place candles in their windows at nine in the evening. The 'barbarism' and world communism that was imprisoning Poland and Europe was denounced. As articulated during this protest, the actions organized by Polonia communities around the country were meant to free all nations from the 'Gulag Archipelago'. ${ }^{81}$ All funds collected in the Winnipeg diocese during Masses in Roman Catholic parishes on January 16 and 17 were gathered for Poland's aid. ${ }^{82}$ Winnipeg continued to be a major center of protest. In June of 1982, a car protest involving 50 vehicles covered with Solidarity stickers was held. ${ }^{83}$ This event was repeated in October with 100 cars. ${ }^{84}$ In August of that year, a protest was held at the Manitoba Parliament, a symbolic cross of flowers being laid at

78 'Wielka demonstracja w Winnipegu', Czas, Nr. 1, January 2, 1982, 1-3.

79 'Solidarno_z z Polskim Narodem', Czas, Saturday, January 18, 1982, 2.

80 'Solidarno_z z Polskim Narodem', Czas, Saturday, January 18, 1982, 2.

81 'Kongres Polonii Kanadyjskiej Oddzia_Manitoba', Czas, Nr. 18, Saturday, May 8, 1982, 1, Czas, Nr. 20, Saturday, May 22, 1982, 3.

82 'Wielka Pomoc Uchod_com Polskim', Czas, Saturday, January 23, 1982, 2.

83 'Manifestacj_Solidarno_i', Czas, Nr. 25, Saturday, June 26, 1982, p 1.

84 'Kolejna demonstracja samochodów Polonii w Winnipegu', Czas, Nr. 43, October $30,1982,2$. 
its steps. ${ }^{85}$ This event was repeated in Edmonton in August 1983 in commemoration of the third anniversary of the founding of Solidarity. ${ }^{86}$ A similar event was held the following month, featuring a car protest of 100 vehicles, the selling of Solidarity t-shirts and flags, and displays of interned political prisoners at the Church of the Holy Rosary. ${ }^{87}$

Although massive, public demonstrations were the usual modus operandi of these groups to call public attention to the plight of Poland and its refugees, they also regularly organized various public displays and exhibits. This included a premier of Andrzej Wajda's film on the movement, Man of Iron in Toronto cinemas in November $1981,{ }^{88}$ a June 1982 photographic and documentary exhibit on Solidarity in the Metropolitan Toronto Library, ${ }^{89}$ and a February 1982 benefitory concert in Calgary, supported by then mayor, Ralph Klein. ${ }^{90}$ In March of 1982, Jan Pietrzak, a Polish comedian and musical performer known for satirizing the PRL regime, came to Canada on tour, fearing to return. ${ }^{91}$ A dinner was organized in his honor at a fund-raising event soon after, intended to raise funds for him to bring back to Poland. ${ }^{92}$ In 1983 protests were still common, and in March of that year the Minister of Cultural Affairs, Eugene Kostyra, admitted to having taken part in a

\footnotetext{
85 'Robotnicze Demonstracje 'Solidarno_i' Krwawo St_umione przez rezym', Czas, Nr. 36, Saturday, September 11, 1982, 1.

86 'Polonia Winnipeska Manifestuj_!', Czas, Nr. 35, September 3, 1983, 1.

${ }^{87}$ Czas, Nr. 37, September 17, 1983, 4.

88 'Solidarity: The Story of the movement that's shaking the world', Kurier PolskoKanadyjski, Nr. 18, November 7, 1981.

89 'Wystawa 'Solidarno i', Kurier Polsko-Kanadyjski, Nr. 11, June 7, 1982, 2.

90 'Concert for Poland', $\bar{C}$ zas, Nr. 8, February 27, 1982, 4.

91 7. Mark Lukasiewicz, 'Life in limbo with Poland's Mr. Cabaret', The Globe and Mail, Saturday, March 20, 1982, Entertainment section.

92 15. Zena Cherry, 'Polish writer at fund-raiser', The Globe and Mail, Monday, April 5, 1982, News section.

Past Imperfect

13 (2007) | @ | ISSN 1192-1315
} 
demonstration where the Soviet flag was burned. ${ }^{93}$ Hunger strikes were also held; a November 1983 issue of the Kurier published photographs of ten hunger strikers demonstrating in front of the Polish consulate. ${ }^{94}$ Hunger strikes were still being reported in Toronto in 1984 and 1985, with strikers demanding that their families be allowed to join them in Canada. ${ }^{95}$

The refugee 'problem' was a strong topic of debate in Canadian society at this time. Many debates took place over the refugees' plights in Austria and the sponsorship schemes and methods employed to bring them to Canada. Lloyd Axworthy, then Immigration Minister, was often caught in the cross fire of debate over provisions made to Polish refugees. ${ }^{96}$ Angry letters were also directed at the Federal Government and Prime Minister Trudeau, whose comments on martial law being preferable to Soviet invasion led some to accuse him of supporting totalitarian and communist regimes, ${ }^{97}$ calls being made against him from Polish constituencies to their MPs. ${ }^{98}$ Polish communities nation-wide sent letters to Trudeau condemning Martial Law and expecting a similar reaction from elected leaders, one resolution reminding Trudeau that 10,000 Soviet

93 8. Richard Cleroux, 'Flag burning is a hot topic', The Globe and Mail, Thursday, March 31, 1983. National section.

94 'G_oduj_cy Polacy przed kolsulatem PRL', Kurier Polsko-Kanadyjski, Nr. 18 (392), Nov. 21, 1983, 1.

95 'Hunger strikers show solidarity', The Toronto Star, Monday, June 4, 1984, A18. Drew Fagan, 'Third Polish faster embraces family after three years', The Globe and Mail, Wednesday, January 30, 1985, 1. Although the articles do not discuss the Soviet reaction to such protests and the burning of its flag, other publications and articles published later also discussed the strikes, which were partially effective in having the families of the striker's freed to join them in Canada. An interesting piece of parallel research would be to examine the Soviet reaction to such protests.

96 'On a jarring note', The Globe and Mail, Friday, October 30, 1981, 6.

${ }^{97}$ V. Walter Petryryshyn, 'Letters to the editor', The Globe and Mail, Thursday, January 21, 1982, 6.

98 'Trudeau tempers remarks on Poland', The Toronto Star, Sunday, January 3, 1982, B7.. 
troops were stationed in Poland..$^{99}$ Leaders of the Polonia community eventually met with Trudeau and were satisfied at a modified position that included a degree of support in the case of any NATOled actions against the USSR. ${ }^{100}$

Around the same time a controversy was developing around the seeming lack of support for private sponsors for Polish refugees. 76 Government levels for the sponsorship of East European refugees in 1982 were set at 6000. Only around 200 Polish refugees were privately sponsored by Polonia organizations that year. ${ }^{101}$ Some of the blame for the low numbers was directed at the Canadian Polish Congress, whose rules for sponsorship were even more stringent than those set by the Canadian government. ${ }^{102}$ According to Jan Kaszub, president of the Canadian Polish Congress, many people applied as self-exiles rather than being privately sponsored, as this would have given them an allowance. Also, they did not want to burden others with having to pay all of their expenses for a year. ${ }^{103}$

Letters to the Toronto Star and The Globe and Mail also reveal tensions within Canadian society in attitudes towards Polish immigrants. A controversial debate was sparked off when Axworthy announced that 1982 quotas for south-east Asian refugees would be set at 4000, half of what they were in 1981, while East European quotas were set for 6000, a move which some Vietnamese and East Indian advocate groups decried as being racist and giving

\footnotetext{
99 'Rt. Hon. Pierre Trudeau', Czas, January 2, 1982, 2.

100 'Polish-Canadian leaders content with PM's stand', The Toronto Star, Tuesday, January 26, 1982, A16.

${ }^{101}$ Mark Lukasiewicz, 'New group to aid Poland's refugees', The Globe and Mail, Tuesday, April 6, 1982, 14.

${ }^{102}$ Zdzis_aw Knobel, 'Polish refugees still wait', The Globe and Mail, Thursday, April 22, 1982, 14.

${ }^{103}$ Bruce Ward, 'Polish Canadians rapped over exiles', The Toronto Star, Wednesday, January 27, 1982, A10. 
preferential treatment to Poles, ${ }^{104}$ while other groups argued that Canada's quotas were racist towards Poles in comparison to the admission of 50,000 Vietnamese several years before. ${ }^{105}$ Other letters from readers revealed strong levels of support for Polish refugees, arguing that the excellent record of Polish immigrants in Canada's past should be a demonstration that they would once again make exceptional immigrants, ${ }^{106}$ others arguing that Poles had suffered under Russian oppression for centuries and that more should be allowed to emigrate. ${ }^{107}$ Andrzej Tatar, billeted in an Austrian gasthof, described how he considered it unlikely that he would ever see Canadian soil, but still preferred life in Austria to Poland. ${ }^{108}$ Another letter made appeals for a sponsor and for any available job, ${ }^{109}$ while a writer from London appealed for a place to stay, having been guaranteed entry upon that condition. ${ }^{110}$ Others expressed anger and frustration. One individual, waiting ten months for permission to emigrate without a reply, discusses how he will have a permanently tarnished image of Canada. ${ }^{11}$

Many of the refugees who eventually found sanctuary in Canada did not come to the country directly from Poland, but often entered via a third country, such as West Germany or Austria. ${ }^{112}$

${ }^{104}$ Peter Goodspeed, 'Ottawa cuts leave boat people stranded refugee-aid group says', The Toronto Star, Wednesday, November 4, 1981, A3.

Liane Heller, 'UN plan means more Indochinese - Axworthy', The Toronto Star, Wednesday, November 4, 1981, A3.

${ }^{105}$ Mark Wegierski, 'Visa policy', The Globe and Mail, Wednesday, October 28, 1981, 7.

${ }^{106}$ Darcy G. Rector, 'Welcome the Poles', The Globe and Mail, Tuesday, August 25, 1981, 7 .

${ }^{107}$ C. Kiss, 'Visa policy', The Globe and Mail, Wednesday, October 28, 1981, 7.

${ }_{108}$ Andrzej Tatar, Kurier Polsko-Kanadyjski, Nr. 12, June 21, 1982, 2.

109 'Listy do Redakcji... Prosba o Sponsora', Kurier Polsko-Kanadyjski, Nr. 3, Feb. 1983, 2.

110 'Listy do Redakcji', Kurier Polsko-Kanadyjski, Nr. 4, Feb. 21, 1982, 2.

111 'Listy do Redakcji'... 'Walka o Dusz,', Kurier Polsko-Kanadyjski, Nr. 12, June 21, 1982, 2.

${ }^{112}$ Badasu, Polish Immigration to Alberta since 1980, 53-63, 92-93. 
Prior to the declaration of martial law, thousands of Poles had fled the country via the 'Chopin Express' train line from Warsaw to Vienna. ${ }^{113}$ Austrian authorities frequently called upon the Canadian government to assist them with the massive number of refugees in the country, which, the Globe and Mail claims, had become a traditional haven for people fleeing from Soviet bloc countries under 78 the terms of its neutrality following WWII. There were 10,000 estimated refugees in Austria in October of 1981, with costs for their care being projected at 18 million. ${ }^{114} 115$ The main refugee camp was Traiskirchen, located near Vienna. People either left Poland by train or car, then escaping into one of the Western countries. One 1981 Star article discussed the fears that many Poles in the refugee camps held regarding the political situation, including worries that Solidarity would soon be crushed by the Soviets. Costs for their care soared and complaints from residents in nearby towns were frequent. ${ }^{116}$ By March of 1982 there were 50,000 Poles staying in refugee camps and private accommodations throughout the country at that time. The author of the letter, an Austrian woman, describes the disappointment felt by many Austrians and Poles at the lack of action being shown by the Canadian government. ${ }^{117}$ By early 1982,

\footnotetext{
113 'Officials uncertain on visa applications', The Globe and Mail, Wednesday, December 23, 1981, 11.

114 'Austrians request help over Polish exile influx', The Globe and Mail, Tuesday, June 23, 1981, 2.

${ }^{115}$ Although other Western European countries, including West Germany, Sweden and Italy, were also preferred destinations for Polish and other refugees from the Soviet bloc, Austria in particular was flooded with Polish Solidarity refugees. Although several of the Canadian and Polish-Canadian articles that I surveyed examined the cases of refugees entering Canada from Sweden, West Germany and Italy, the vast majority of media and popular attention was focused on Polish refugees from Austria. Detailed information on refugees entering other countries, such as the United States or South Africa, was sparse in my sources. Badasu, 53-65.

${ }^{116}$ Harry Trimborn, 'Fearful Poles flee in thousands', The Toronto Star, Saturday, July 11, 1981, B6.

${ }^{117}$ Inge Rabinger, 'Polish refugees', The Globe and Mail, Thursday, March 11, $1982,7$. 
tensions in the camps were running high, with occasional fights breaking out between Austrians and refugees in communities near the camps. ${ }^{118}$ By this time, Vienna had begun to consider taking steps to halt immigration, including the introduction of visas for incoming Poles. Estimates were made that fifty million dollars had been spent for their care. The camps were already close to capacity and people were being billeted in hotels. ${ }^{119}$

In April of that year, Jan Kaszub, president of the PolishCanadian Congress, prepared to personally visit camps in Austria and Italy in order to collect personal information on people, make appeals to Western governments, and assist refugees in finding sponsors. ${ }^{120}$ Personal accounts have been compiled of experiences in these camps. After arriving in Traiskirchen, one man and his family was interviewed, fingerprinted, and placed on file. He describes aspects of camp life, including the accommodations and social activities, which often included brawling, drinking, card playing, and participation in language courses, particularly English. He also emphasized the strong feelings of monotony and the frustrations experienced in dealing with the often difficult and taxing interview processes for emigration. ${ }^{121}$ Another personal account emphasized the feeling of despair and anxiety felt by the author, unable to reach his relatives in Poland. He describes how Traiskirchen had two huge halls filled with beds lined up side-to-side, 50 or 60 in each. Food was served several times per day, and regular discussions took place on rumors and news from Canada and on its immigration policy. On

\footnotetext{
118 'Austriacy s_niech_tni wobec polskich ochod_cow', Kurier Polsko-Kanadyjski, Nr. 1 (354), Jan 7, 1982, 1.

119 'Polscy Uchod_cy w Austrii', Czas, December 19, 1981, 1.

${ }^{120}$ Jan Kaszub, 'List Otwarty', Kurier Polsko-Kanadyjski, Nr. 7, April 7, 1982, 1.

${ }^{121}$ Zió kowska, Dreams and Reality, 251-264.

Harry Trimborn, 'Fearful Poles flee in thousands', The Toronto Star, Saturday, July 11, 1981, B6.
} 
Saturdays, a Polish language Mass was held, and Wajda's Man of Iron was also shown on occasion. ${ }^{122}$ Serious problems had developed at border crossings by November of that year, with high numbers of illegal crossings. Tensions ran high after one person was shot by Czech border police. The Procurator General warned that people caught trying to leave would be punished by no less than three years in prison, with people leaving certain occupations judged integral to the economy being considered deserters and tried by military tribunal. ${ }^{123}$

Polish refugees searched for many methods through which to escape into Canada from what they saw as an oppressive social and economic environment. In October of 1981, when a cruise ship docked in Montreal, 106 of the 271 Polish passengers refused to return. Eighty more, holding tourist visas, were also preparing to apply for refugee status. An airplane flying in from Vienna with 100 Polish passengers had landed in Montreal the day before, with the majority refusing to return. ${ }^{124}$ In December of that year, 157 sailors from two Polish fishing boats that had docked in Vancouver, although worried about their families, refused to return. ${ }^{125}$ Later that year, several articles were published that discussed the lives, hopes and fears of some of these seamen and their adjustments to Canadian society. Many of them were working on ministerial visas that had allowed them to stay and work in Canada for one year, and expressed their concern at being unable to stay in touch with their families. The articles also discussed how the seamen read history books and

\footnotetext{
122 'Uciec jak Najdalej', Czas, Saturday, December 13, 1981, 1.

123 'Niedane Próby Ucieczek z PRL Do Austrii i NRF', Kurier Polsko-Kanadyjski, Nr. 20 (374), Nov. 21, 1982, 1.

${ }^{124}$ Victor Malarek, ' 110 Poles opt to stay behind as cruise ship leaves Montreal', The Globe and Mail, Saturday, October 31, 1981, 18.

${ }^{125}$ Ian Mulgrew, 'Ship sailing awaits seamen's vote', The Globe and Mail, Wednesday, January 13, 1982, 12.

Past Imperfect

13 (2007) | @ | ISSN 1192-1315
} 
exposed themselves to anti-Soviet views, unavailable in Poland at the time due to censorship, helping to raise their feelings of national awareness. $^{126}$

A great variety of initiatives were organized across Canada to find ways to bring in and support more refugees. The extent to which Polonia organizations had mobilized around the refugee and political issues and had taken on a degree of responsibility for helping out this 'enigmatic third wave' can be highlighted in an October 1982 appeal in Czas, wherein it is stated that these issues are not just the concerns of a few individuals or families, but of the entire Polish community. ${ }^{127}$ In October 1981, the Polish-Canadian Congress of Toronto appealed to people to help refugees enter the country, either through a donation of money or food, places to stay, or offers of work. ${ }^{128}$ In December 1981, the Polish community of Sudbury, Ontario welcomed eight Polish families, inviting them to celebrate Christmas traditions together and making appeals to the community to help them find a place to stay. ${ }^{129}$ The newspaper Czas offered 100 free, three month subscriptions to people who had recently arrived from Poland, emphasizing how through funding this, people could 'fulfill their patriotic call for our brothers in the homeland'. ${ }^{130}$ Throughout the country, many people in the community volunteered to help. In February 1982, the Polish Refugee Fund of Kingston, Ontario, had collected $\$ 20,000$ to help settle people, bringing in fifteen individuals from Austria. ${ }^{131}$ In

\footnotetext{
${ }^{126}$ Ian Mulgrew, 'Fear for families clouds lives of Polish refugees', The Globe and Mail, Friday, October 29, 1982, 17.

127 'Polonia w Winnipegu i Pomoc Polakom Uchod_com', Czas, nr. 43, October 30, 1982, 2.

128 'Apel Kongresu Polonii Kanadyskiej Okr_g Toronto', Kurier Polsko-Kanadyjski , Nr. 17, Oct 21, 1981, 2.

129 'Wie_ci z Sudbury, Ont', Kurier Polsko-Kanadyjski, Nr. 21, Dec. 21, 1981, 8.

130 'Ka_dy Nowoprzyby_y Prenumeratorem CZASU!', Czas, December 19, 1981, 1.

131 'Pomoc Uchod_com Polskim', Czas, February 13, 1982, 4.
} 
Winnipeg, special collections of money and winter coats were organized in city schools. ${ }^{132}$ A family that had settled in Regina, Saskatchewan expressed gratitude to their sponsors, reflecting on how different their lives would be from then on as they celebrated their first Christmas and New Year in Canada. ${ }^{133}$ A Toronto family sponsored a group, including a father suffering from tuberculosis, 82 paying for all of their medical and dental treatments as well as furnishing them with an apartment. ${ }^{134}$ These described instances are a microcosm of similar processes that were occurring on a much larger scale throughout the country during this time.

The twentieth century in Poland was a traumatic period, characterized by warfare, economic, social, political, and religious impoverishment and persecution. The Polish people have a long history of migration and participation in Canadian social, economic and political life. The rise of the Solidarity movement in the early 1980s not only set off a spark of revolutionary change in the Soviet bloc that ultimately led to its dissolution and the fall of Communism in Poland and throughout the region, it also led to a change in the social dynamics of immigration and integration, yielding the most vocal and politically active group of Polish immigrants that both Canadian and Polish-Canadian society had seen. The betrayal of human rights and the political persecution in their ancestral homeland led Polish communities throughout Canada to mobilize on an unprecedented scale. Through an examination of the methods through which these groups lobbied the Canadian government, their organization of aid drives, and the assistance they provided to

132 'Ludzie Dobrej Woli', Czas, February 20, 1982, 2.

133 'Korespondencja $z$ Regina: Pierwsze _wi_ta Bo_ego Narodzenia w Kanadzie', Czas, Saturday, January 22, 1983, 3.

${ }^{134}$ Elaine Carey, 'A community growing out of hardship', The Toronto Star, Thursday, July 28, 1983, D1. 
refugees to enter and settle the country, the substantial impact that an ethnic group can play on the social and political dynamics of the wider state of which they constitute a part of, as well as the effects that refugee and sudden immigration influxes play on an ethnic community, has been demonstrated to be a very dynamic and multifaceted process, one which has worked to permanently restructure the social makeup of the Polish-Canadian community and in how it relates to mainstream Canadian government and society. 